\title{
Mitä Agricolan pitikään tarkoittaman?
}

DuHa ElsAYeD: Agricolan pitää - nesessiiviverbi kielikontaktin ytimessä. Turun yliopiston julkaisuja C488. Turun yliopisto, Turku 2018. 225 sivua ja 4 liitesivua.

Filosofian maisteri Duha Elsayedin väitöskirja tarkastelee pitää-verbin käyttöä Mikael Agricolan teoksissa. Tavoitteena on selvittää sitä, miten pitää-verbi on valikoitunut niihin toisistaan melko paljonkin poikkeaviin tehtäviin, joissa se Agricolan kielessä esiintyy. Päähuomio kohdistuu kielikontaktien, erityisesti ruotsin kielen skulla-verbin, vaikutukseen.

Tutkimuksen aihe on fennistisesti merkittävä ja haastava: se liittyy useisiin aiempiin tutkimuksiin ja tarkastelee sinänsä melko paljon tutkittua ilmiötä ja aineistoa. Aiheen valintaa voikin luonnehtia rohkeaksi siinä mielessä, että pitää-verbiä ovat aiemmin tutkineet väitöskirjoissaan ja muissa kirjoituksissaan esimerkiksi sellaiset suomen kielen tutkimuksen suuret nimet kuin Osmo Ikola (esim. 1949; 1950; 1974) ja Lea Laitinen (1992). Vielä enemmän on kirjoitettu Agricolan kielestä, ja nimenomaisesti Agricolan pitää-verbin käyttökin on ollut aiemman huolellisen tutkimuksen kohteena. Elsayed onnistuu kuitenkin rakentamaan aiheeseen tuoreen näkökulman, joka tuottaa kiinnostavaa uutta tietoa niin pitää-verbin historiasta kuin Agricolan kielestä ja Agricolasta itsestään kääntäjänä ja kielenkäyttäjänä.

\section{Tyvestä latvan kautta puuhun}

Kirjan rakenne noudattaa pääosin tekstilajinsa konventioita. Luvussa 1 tekijä esittelee työnsä lähtökohdat, tutkimuskohteen ja tutkimusongelman. Luvussa 2 hän käy läpi "kielitieteen ilmiöt, joita tämä tutkimus koskettaa”, kuten luvun nimi kuuluu. Samalla hän esittelee tutkimuksensa melko monenlaisia taustateorioita. Varsinainen analyysiosuus sijoittuu lukuihin 3-5. Niiden 
osalta asioiden esittämisjärjestys kenties poikkeaa hiukan totutusta. Useinhan on tapana, että analyysi lähtee liikkeelle yleisemmistä havainnoista ja syvenee edetessään kohti yksityiskohtaisempia kysymyksiä ja havaintoja.

Elsayedin etenemissuunta on kuitenkin päinvastainen. Luvussa 3 hän tarkastelee Agricolan pitää-verbin erilaisia futuurisia ja futuurisen kaltaisia käyttöjä nimenomaan Agricolan kääntämien evankeliumitekstien valossa. Tarkastelu on yksityiskohtaista, ja siinä tekijä paneutuu paitsi yksittäisten aineistoesimerkkien semanttisiin tulkintoihin myös käännösten lähtötekstien merkitykseen käännösprosessin ja sen lopputuloksen kannalta. Luvussa 4 tarkastelu on laaja-alaisempaa: se kohdistuu Agricolan tuotantoon evankeliumeja laajemmin ja pitää-verbin käyttöön yleisemmin. Näin ollen analyysi ei edetessään juurikaan syvene vaan pikemminkin päätyy taustoittamaan luvun 3 havaintoja.

Luvussa 5 tekijä palaa perinteiseen esittämisjärjestykseen ja tarkastelee aineiston analyysissa esiin tulleiden havaintojen päälinjoja ja niistä nousevia johtopäätöksiä. Tarkastelu on kiinnostavalla tavalla monipuolista: Yhtäältä se hakeutuu näkemään kääntäjä-Agricolan elävänä ihmisenä ja selittämään käännösratkaisuja ja niiden vaikutuksia pitää-verbin käyttöön tästä näkökulmasta. Toisaalta siinä ollaan suurten teoreettisten kysymysten äärellä ja pohditaan mm. kielikontaktien tutkimuksen käsitteistön ja konstruktiokieliopin teoreettisten välineiden yhteensovittamista. Pääosassa on kuitenkin koko ajan Agricolan pitää-verbin käyttö. Tämä pieneltä ja viattomalta vaikuttava verbi osoittautuu työssä "kokoaan suuremmaksi", kuten lyhyen loppuluvun otsikko asian ilmaisee. Sen kautta avautuu näköaloja muun muassa modaalisuuden, tempusjärjestelmän, moniäänisyyden, kääntämisen, kielikontaktien ja morfosyntaksin suuntiin. Ei siis ihme, että se taipuu osaavissa käsissä ansiokkaiden fennististen väitöskirjojen aiheeksi sukupolvesta toiseen.

\section{Teoriatausta, aineisto ja menetelmät}

Kaikkiaan teos on rakenteeltaan toimiva ja johdonmukainen. Kokonaisuuden kannalta siinä tosin on melko runsaasti taustoittavaa osuutta, eikä tekijä käy aivan suoraan kiinni varsinaiseen analyysiinsa: lukija kohtaa ensimmäisen numeroidun aineistoesimerkin vasta ensimmäiset sata sivua luettuaan. Erityisesti ruotsin skola- ja suomen pitää-verbin eroja ja yhtäläisyyksiä käsittelevä osuus tästä pohjustuksesta on kuitenkin ansiokas. Sisällöllisesti tarkastellen konstruktiokielioppiin ja konstruktioiden luonteeseen ja toisaalta myös kielikontaktitutkimukseen paneutuva osuus taustoituksesta jää aiheeseen nähden valitettavan vähäiseksi; toisaalta kirja ei ole suppea tällaisenakaan, ja tekijän valitsemat painotukset ovat ymmärrettäviä.

Menetelmiltään ja taustateorioiltaan työ on monipuolinen. Siinä yhdistyvät perinteisen filologisen tutkimuksen lähtökohtien lisäksi modernin kielikontaktien tutkimuksen ja kieliopillistumisteorian ainekset sekä konstruktiokieliopin nimellä tunnettu kielenkuvausmalli. Nämä ainekset ovat keskenään melko erilaisia mutta, kuten Elsayed työssään osoittaa, sillä tavoin yhteensopivia, että niiden keskenään osin erilaisten tavoitteiden ja vahvuuksien yhdistäminen samassa tutkimuksessa tuottaa sellaisia havaintoja, mihin mikään näistä lähestymistavoista yksin ei yltäisi.

Työ osoittaa tekijänsä huomattavaa perehtymistä relevanttiin tutkimuskirjallisuuteen. Erityisesti tämä näkyy luvussa 2, jossa tekijä esittelee työn keskeiset teoreettiset vaikuttimet. Oman alalukunsa ovat saaneet kieliopillistumisteoria, konstruktiokielioppi ja kielikontaktien tutkimus. 
Aineksia on runsaasti yhteen tutkimukseen, ja luku osoittaakin kirjoittajan laajaa lukeneisuutta ja perehtymistä erilaisiin tutkimussuuntauksiin. Luku 2 jättää kuitenkin lukijalleen hiukan epätasaisen ja jäsentymättömän vaikutelman: monin paikoin se tuntuu kokoelmalta kirjallisuudesta poimittuja yksityiskohtia, joita tekijä luettelee lähdeteos ja tekstikappale kerrallaan. Toisiinsa usein kovin väljästi liittyviä sitaatteja ja referoituja jaksoja on niin tiheässä, että tekijän oma ääni tuntuu paikoin hukkuvan niiden alle. Teksti tuntuu myös jonkin verran toisteiselta, mikä johtuu osin jäsennyksen puutteista. Tällaiset ongelmat ovat toki ymmärrettäviä silloin, kun teoriakirjallisuutta käydään läpi niin monipuolisesti kuin tässä on tehty.

Sivulla 90 käy ilmi, että "tutkimuksen aineistona on koko Agricolan tuotanto" ja että "kaikki nesessiivisen pitää-verbin esiintymät lauseyhteydessään on kerätty manuaalisesti, lukemalla kootut teokset”. Menetelmä vaikuttaa kunnioitusta herättävässä perusteellisuudessaan työläältä; lukija jää pohtimaan, eikö olisi ollut huomattavasti helpompaa ja kenties luotettavampaakin hakea esiintymät sähköisestä korpuksesta automaattisesti. Toki tekijä on hyödyntänyt myös sähköisiä korpuksia, ja manuaalinen aineistonkeruu on ilmeisesti ollut yhtäältä kattavuuden varmistamista ja toisaalta aineiston läpikäyntiä ja analysointia.

Toisaalta tekijä ei käytä likikään koko keräämäänsä aineistoa kaikkeen analyysiin vaan rajaa merkittävän osan tarkastelua Luukkaan evankeliumiin. Agricolan tuotanto on kuitenkin sisäisesti sangen heterogeeninen, kuten työssä toistuvasti todetaankin, ja tiedetään, että evankeliumit poikkeavat kieleltään jonkin verran Agricolan muusta tuotannosta. Monien ilmiöiden esiintymämäärät varsinkin pelkässä Luukkaan evankeliumissa ovat sitä paitsi niin pieniä, että aineiston koko uhkaa nostaa sattuman merkittäväksi tekijäksi siinä, mitä tutkijan haaviin lopulta osuu.

\section{Havaintoja tutkimuksessa ja tutkimuksesta}

Elsayedin väitöskirja on pitkäaikaisen tutkimustyön tulos. Työn pituus ja perusteellisuus näkyy niin hyvässä kuin pahassa: aineksia ja aihepiirejä kirjassa on useammankin tutkimuksen tarpeisiin, mutta toisaalta lukija toivoisi kirjoittajan valottavan tietämystään vielä laajemmin. Tällaisenakin työ tarjoaa silti monia antoisia näkökulmia nesessiivisen tai futuurisen pitää-verbin ympärille rakentuneisiin ilmauksiin Mikael Agricolan teoksissa. Se valottaa pitää-verbin käyttöjen ja historian ohella Agricolan itsensä kääntäjänominaisuuksia, kieltenvälisten kontaktitilanteiden seurauksia ja monia muitakin teemoja.

Aineistoesimerkkien vertailu eri lähtöteksteihin on työn kannalta tavattoman antoisaa. Valitettavasti se ei ole aivan niin systemaattista kuin soisi ja jää lopulta pienempään rooliin kuin lukija kenties toivoisi. Vertailu on toki tavattoman työlästä ja vaativaa, joten on huomattavan ansiokasta, että tekijä on siihen näinkin laajasti paneutunut. Samoin on selvää, ettei olisi ollut mielekästä pyrkiä selvittämään järjestelmällisesti kaikkien esimerkkiensä todennäköisiä ja mahdollisia lähtötekstejä, eikä se kaikkien tarkasteltavien asioiden kannalta olisi tarpeenkaan. Monin paikoin lukijaa kuitenkin hämmentää se, miten voimakkaasti tekijä painottaa juuri ruotsinkielisten lähtötekstien asemaa Agricolan käännöksissä.

Vaikka saatavilla olevaa laajaa aineistoa ei ole hyödynnetty likikään täysimääräisesti, esiin nousee kiinnostavia ilmiöitä ja joitakin arvokkaita oivalluksia. Erityisen kiinnostavana näyttäytyy luvussa 2.2.5 ikään kuin ohimennen esitetty ajatus pitää-verbille esitetyn 'tekemiseen tarttumisen' merkityksen rinnastumisesta sellaisiin lähinnä dynaamista modaalisuutta ilmaiseviin 
verbeihin kuin pystyä, mahtaa, ylettää ja rohjeta. Tästä avautuu sangen kunnianhimoinen hypoteesi pitää-verbin käytön ja merkityksen kehittymisen selittämiseksi. Valitettavasti tekijä ei kehittele tätä ajatusta loppuun saakka. Hän toteaa (s. 56): "Ajatus 3. infinitiivillä täydentyvästä pitää-verbistä mahdollisuuden ja riittävyyden verbinä saattaa aluksi oudoksuttaa, koska on puhe suomen kielessä niin keskeisestä välttämättömyyden verbistä." Tämä on totta; lisäksi ongelmana on, ettei pitää-verbin käytöstä tässä esitetyllä tavalla dynaamista mahdollisuutta ilmaisevana verbinä taida juuri olla osoitettavissa jäänteitä missään. Haasteistaan huolimatta ajatus vaikuttaa niin oivaltavalta ja selitysvoimaiselta, että sille kaipaisi huolellista jatkokehittelyä ja argumentointia.

Samoin ongelmalliselta vaikuttaa datiivigenetiivin asema uudelleenanalyysissa. Sivulla 55 tekijä viittaa Nobufumi Inaban (2015) tutkimukseen suomen datiivigenetiivistä. Hän sanoo Inabaan nojautuen, että datiivigenetiivi "on paljon myöhäisempää perua kuin aikaisemmin on yleisesti ajateltu, eikä se missään tapauksessa ole sellaisenaan voinut olla nesessiivisen konstruktion rakennusaineena”. Kuitenkin tekijä on juuri tätä ennen esittänyt pitää-verbin modaalistumiseen johtaneesta uudelleenanalyysista pitkän ja monipolvisen selityksen, joka kauttaaltaan nojaa juuri datiivigenetiiviin. Tämä ristiriita ei ole helposti sovitettavissa: Inaban tutkimus asettaa merkittävän haasteen koko suomen infinitiivirakenteiden tutkimukselle, eikä datiivigenetiivin ongelmaa olisi käsillä olevan työn puitteissa voinutkaan kohtuudella selvittää.

Työn lopulla, kohdassa 5.5, tekijä esittää melko rohkean ajatuksen siitä, että Agricolan pitää-verbi oikeastaan kongruoi subjektinsa kanssa paljon useammin kuin on totuttu ajattelemaan. Kongruenssia ei vain yleensä huomaa, koska verbi on niin usein yksikön 3. persoonassa. Tämä on, kuten tekijä (s. 207) toteaakin, mieluummin ajatusleikki kuin todennettu asia, mutta kiinnostava se on - erityisesti, koska nominatiivisubjekti on Agricolalla yleisemmässä käytössä kuin nykykielessä. Tähän ajatusleikkiin voisi vielä lisätä yhden havainnon, jota tekijä ei ole huomannut: sattumaa tai ei, Agricolan kotipitäjä Pernaja sijoittuu juuri sille melko suppealle kaakkoishämäläiselle murrealueelle, jossa kongruoivaa nesessiivistä pitää-verbiä ylipäätään tavataan.

Yksi työn ansioista on se, että tekijä on pyrkinyt esittämään eräitä keskeisiä havaintojaan ja tulkintojaan konstruktiokieliopin kuvausformalismin avulla täsmällisessä muodossa. Tämä havainnollistaa formalismin tuntevalle eri rakenteiden - tai rakenteen eri tulkintavaihtoehtojen - ominaisuuksia selkeässä ja yksiselitteisessä muodossa. Valitettavasti formalisoinneissa on jonkin verran ongelmia, ja ne kielivät siitä, ettei tekijä ole sisäistänyt konstruktiokieliopin piirrekuvausta aivan kaikilta osin.

Sivulla 205 tekijä sanoo konstruktiokieliopin mukaisen kuvauksen tarjoamista hyödyistä mm. näin: "On tiedossa, että vanhan kirjasuomen koetusta muukalaisuudesta suuri osa on ruotsin vaikutusta. Silti kontaktikieliopillistumiseen kuuluva kopiointi toteutetaan määritelmän mukaisesti kohdekielen omia, olemassa olevia konstruktioita hyödyntämällä. Konstruktioteorian mukainen lähestymistapa tekee tämän näkyväksi." On tietysti totta, että tämä kohdekielen omien rakenteiden hyödyntäminen tulee eksplisiittisesti näkyväksi. Toisaalta kontaktitilanteen kuvauksessa pitäisi kuitenkin tuoda näkyviin myös se vieraan kielen vaikutus, joka toimii muutoksen mallina. Tähän konstruktiokielioppi ei nykyisellään tunnu taipuvan. Haasteeksi jää sellaisen kuvausmallin tai formalismin kehittäminen, joka toisi esille myös kontaktitilanteissa yhteen sovitettavien rakenteiden kahtalaisuuden.

Työn loppupuolella, sivulla 207, tekijä lausuu ääneen ongelman, joka on vaivannut lukijaa pitkin matkaa: "Agricolan pitää-konstruktioiden subjektin sijasta olen tässä tutkimuksessa 
onnistunut sanomaan vain sen, että sanaluokka vaikuttaa sijanvalintaan.” Tämä on valitettavaa, koska subjektin sijanmerkintä on keskeinen rakenteen hahmottamisen indikaattori, ja yllättävää ottaen huomioon sen, miten paljon nesessiivirakenteen subjektin sijanmerkinnästä on aiemmin kirjoitettu. Kohtalonkysymys se ei käsillä olevan työn kannalta sentään ole, koska päähuomio on rakenteen laajemmissa semanttisissa tulkinnoissa ja niiden taustoissa.

\section{Lopuksi}

Duha Elsayedin väitöskirja osoittaa tekijänsä laaja-alaista perehtymistä aihepiiriä käsittelevään tutkimuskirjallisuuteen ja erilaisiin tutkimussuuntauksiin. Samoin työ osoittaa tekijänsä syvällistä aineistonsa ja tutkimuskohteensa tuntemusta. Mikael Agricolaa, hänen tuotantoaan ja sen erikielisiä lähtötekstejä esittelevät osuudet tekstistä välittävät vaikutelman, että kirjoittaja liikkuu itselleen tutulla alueella ja kirjoittaa siitä asiantuntevasti eikä vain lähdeteoksia siteeraten ja ulkokohtaisesti. Työ myös onnistuu tuomaan aidosti uusia ajatuksia monilta osiltaan jo aiemmin huolellisesti tutkittuun aihepiiriin.

Kokonaisuudessaan teos on leimallisesti erilaisia suuntauksia yhdistävä ja sijoittuu useiden tutkimustraditioiden risteyskohtaan. Tästä syystä sen anti ei kenties ole jokaisen tradition näkökulmasta erikseen tarkasteltuna erityisen syvällistä - esimerkiksi konstruktiokieliopin, kielikontaktitutkimuksen tai edes vanhan kirjasuomen, johon se kyllä tuo kiistattomasti uutta. Työn suurimmat ansiot ovatkin näkökulman ja kokonaisuuden omaperäisyydessä: se, ettei tekijä pureudu niin syvälle mihinkään yksittäiseen traditioon kuin voisi, johtuu ennen kaikkea siitä, ettei hän sitoudu minkään tradition näkökulmiin ja tarkastelutapoihin sellaisenaan vaan kyseenalaistaa ja uudistaa niitä. Samalla se avaa - tai jättää avoimeksi - useita uusia tutkimusaiheita, joihin tekijän soisi myöhemmin urallaan tarttuvan samalla innolla ja asiantuntemuksella, jolla hän on väitöstutkimuksensa laatinut.

JAAKKO LEINO

jaakko.leino@helsinki.fi Suomalais-ugrilainen ja pohjoismainen osasto

PL 3, 00014 Helsingin yliopisto

\section{Lähteet}

IкоLA, Osmo 1954: Tempusten ja modusten käyttö ensimmäisessä suomenkielisessä raamatussa verrattuna vanhempaan ja nykyiseen kieleen. 1, Johdanto: Indikatiivin presensin ja futuristen liittomuotojen temporaalinen käyttö. Turun yliopiston julkaisuja B32. Turun yliopisto, Turku.

_ 1950: Tempusten ja modusten käyttö ensimmäisessä suomenkielisessä raamatussa verrattuna vanhempaan ja nykyiseen kieleen. 2, Indikativin presensin ja futuristen liittomuotojen temporaalinen käyttö. Turun yliopiston julkaisuja B34. Turun yliopisto, Turku.

InAba, Nobufumi 2015: Suomen datiivigenetiivin juuret vertailevan menetelmän valossa. SuomalaisUgrilaisen Seuran toimituksia 272. Suomalais-Ugrilainen Seura, Helsinki.

LAitinen, LEA 1992: Välttämättömyys ja persoona. Suomen murteiden nesessiivisten rakenteiden semantiikkaa ja kielioppia. SKS, Helsinki. 